\title{
IMPROVING THE ENVIRONMENTAL PERFORMANCE OF VEHICLES UPGRADING THE COOLING SYSTEM OF AN INTERNAL COMBUSTION ENGINE
}

\author{
Zaichenko S.V. ${ }^{1}$, Shalenko V.O. ${ }^{2}$, Zaichenko L.I. ${ }^{1}$, Krupa K.V. ${ }^{1}$ \\ ${ }^{1}$ National Technical University of Ukraine "Igor Sikorsky Kyiv Polytechnic Institute" \\ 37, Peremohy av., 03056, Kyiv \\ ${ }^{2}$ Kyiv National University of Construction and Architecture \\ 31, Povitroflotskyi Av., 03037, Kyiv \\ zstefv@gmail.com,vadshal@i.ua, juk.luda@gmail.com,krupa@gmail.com
}

\begin{abstract}
The article discusses the work of a fundamentally new cooling system for a cylinder-piston group of an internal combustion engine of a vehicle. Ensuring environmental and economic requirements is possible only with the use of powerful engines characterized by elevated temperatures of fuel combustion processes. It is the most thermally loaded part of the internal combustion engine of the cylinderpiston group that is - the piston. High engine piston temperatures cause a number of negative operational and environmental negative effects. Among the existing cooling schemes, a combined system is common. This system requires the installation of a special pump and complex system of channels of the crankshaft. The developed cylinder piston cooling system allows to reduce and stabilize the temperature, which in turn will improve the environmental friendliness, reliability and energy efficiency of using this type of energy source in transport systems. The basis of the operation of the temperature stabilization system of the piston of a vehicle engine is the principle of a vibration pump. The principle of robots consists in acting on a liquid column with a working body and creating a short-term pressure pulse. Stabilization of the piston temperature is achieved by constant washing with a stream of oil, moving along a specially formed channel of the piston walls. To determine the parameters of the system of forced oil cooling of the piston of the engine of an autonomous power source, the acceleration of the connecting rod is determined. Determination of the tangent component of the connecting rod acceleration and the equation of the liquid column under the action of the plunger allows you to set the pressure developing vibration pump and with the known design of the piston channels. The parameters of the flow of the working fluid allow us to determine the amount of thermal energy that is removed by the developed cooling system. Key words: reliability, temperature, vehicle, piston, internal combustion engine, pressure, flow rate.
\end{abstract}

Підвищення екологічних показників транспорту шляхом модернізації системи охолодження двигуна внутрішнього згорання. Зайченко С.В., Шаленко В.О., Зайченко Л.І., Крупа К.В.

У статті розглянуто роботу принципово нової системи охолодження циліндропоршньової групи двигуна внутрішнього згорання транспортного засобу. Забезпечення сучасних екологічних та економічних вимог можливе лише за умови використання потужних двигунів, що характеризуються підвищеною температурою процесів згоряння палива. Саме найбільш термічно навантаженою деталлю двигуна внутрішнього згорання цилідропоршньової групи є поршень. Висока температура поршня двигуна $є$ причиною низки негативних експлуатаційних та екологічних негативних наслідків. Серед схем охолодження поширеною $є$ комбінована система. Ця система потребує встановлення спеціального насоса і складної системи каналів колінчастого валу. Розроблена система охолодження поршня циліндра дає змогу знизити і стабілізувати температуру, що своєю чергою дасть змогу підвищити екологічність, надійність і енергоефективність використання цього типу джерела енергії в транспортних системах. В основу роботи системи стабілізації температури поршня двигуна транспортного засобу покладено принцип вібраційного насоса, що полягає в наданні стовпу рідини робочим органом короткочасного імпульсу тиску. Стабілізація температури поршня досягаєтеся постійним омиванням потоком масла, що рухається по спеціально утвореному каналу стінок поршня. Для визначення параметрів системи примусового масляного охолодження поршня двигуна автономного джерела живлення визначено прискорення шатуна. Встановлення дотичної складової частини прискорення шатуна і рівняння стовпа рідини під дією плунжера дає змогу визначити тиск, який розвиває вібраційний насос і при відомій конструкції каналів поршня. Відомі параметри потоку робочої рідини дають змогу визначити кількість теплової енергії, яка відводиться розробленою системою охолодження. Ключові слова: надійність, температура, транспортній засіб, поршень, двигун внутрішнього згорання, тиск, витрати.

Statement of a problem. Reliable use of vehicles based on internal combustion engines is possible only if the working condition of the source of mechanical energy [1-3]. Among the main internal combustion engines that significantly affect the reliable and energy-efficient operation of the engine should be distinguished cylinder-piston group with the most heat-loaded part among the parts.
The high temperature of the engine piston is the cause of a number of negative operational and environmental negative consequences. The first group includes the effect of high piston temperature on the rate of oil deposits in the groove, coking and as a consequence of occurrence. Improper load distribution between the rings, which leads to loss of tightness of the combustion chamber. 
The breakthrough of the exhaust gases leads to a violation of the lubrication of the piston, which in turn leads to an increase in friction and an even greater increase in piston temperature. These phenomena can lead to the formation of burrs and jamming of the piston with the stop of the generating unit.

Ensuring modern environmental and economic requirements is possible only with the use of high-power engines, characterized by elevated temperatures of fuel combustion processes. Based on the above, it is possible to conclude that the creation of a system that has stabilized the required piston temperature in order to ensure high environmental performance is an important scientific task.

The solution to this problem is possible by intensifying heat transfer to the environment through the use of forced oil cooling of the piston.

The purpose of modeling. The purpose of this study is to develop a system of forced oil cooling of the engine piston of vehicles.

Statement of the basic to materials. To solve this problem, a system of stabilization of the temperature of forced oil cooling of the engine piston by installing a vibrating pump (Fig. 1). The main elements of the system of forced oil cooling of the engine piston are a piston with a system of cooling channels 1 , a piston finger 2 with a groove for oil supply, a connecting rod 3 with a vibrating pump 4 , a tube 5 , a crankshaft 6 . The vibrating pump housing can be made in two continuous with connecting rod and separately by mechanical connection. Given the high dynamic loads, the receiving rod is the preferred option. The cooling system begins to work when alternating accelerations greater than $3 \mathrm{~g}$ [3]. The source of alternating accelerations is the crank shaft which moves the rod when rotating, performing plane-parallel motion. As a result of this motion, the fluid and the piston receive significant accelerations, forcing the fluid to move under the action of inertial forces in the opposite direction of the acceleration vector.

To set the parameters of the system of forced oil cooling of the engine piston, determine the acceleration of the connecting rod. The acceleration of the points of the connecting rod along its length have different directions and meanings. The acceleration points of the connecting rod which are located closer to the piston in the direction coaxial with the cylinder and take values equal to the acceleration of the piston $[4,5]$ :

$$
j_{p}=r \omega^{2}(\cos (\varphi)+\lambda \cos (2 \varphi)),
$$

where $r$ - radius of the crank shaft;

$\omega$ - angular speed of rotation of the crankshaft;

$\lambda=r / L-$ dimensionless coefficient;

$L$ - length of the connecting rod;

$\varphi$ - the angle of rotation of the crank at a given time, counted from the axis of the cylinder in the direction of rotation of the crankshaft.

The acceleration points of the connecting rod close to the crankshaft have a direction tangent to the trajectory of rotation of the shaft and the value:

$$
j_{k}=r \omega^{2},
$$

The value of the acceleration of the middle point of the connecting rod, provided that the pole is a point $K$, it is possible to represent dependence (fig. 2):

$$
\vec{j}_{s}=\vec{j}_{k}+\vec{j}_{k / s}^{n}+\vec{j}_{k / s}^{\tau},
$$

where $\vec{j}_{k / s}^{n}$ and $\vec{j}_{k / s}^{\tau}-$ normal and tangential acceleration of the midpoint relative to the pole.

Since only the components that are directed along the axis of the connecting rod are important for the operation of the vibrating pump, the tangential component

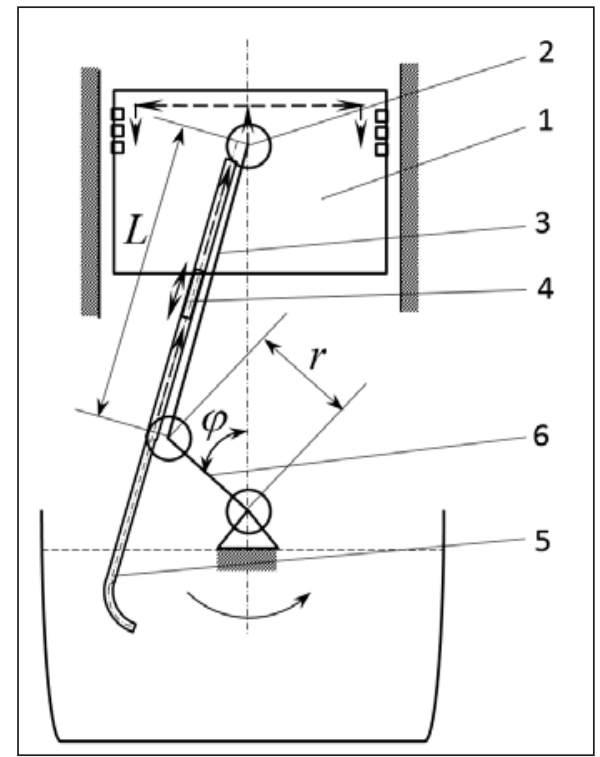

Fig. 1. Functional diagram of forced oil cooling of the engine piston

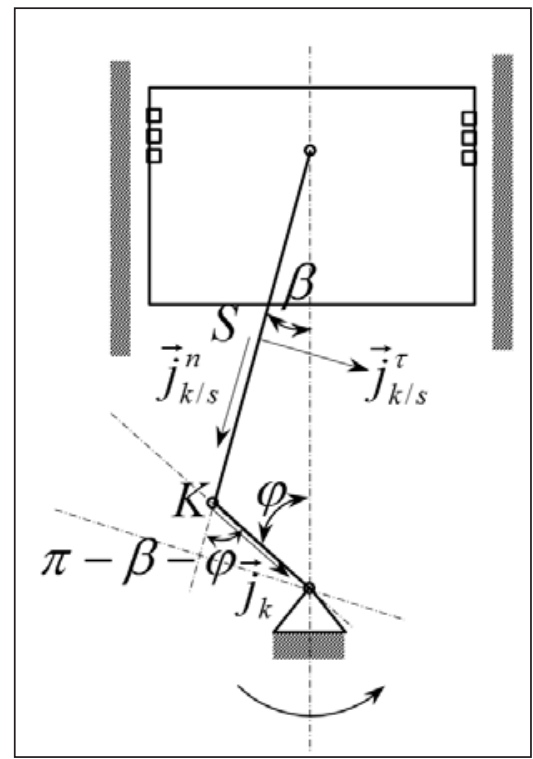

Fig. 2. Kinematic scheme of forced oil cooling of the engine piston 


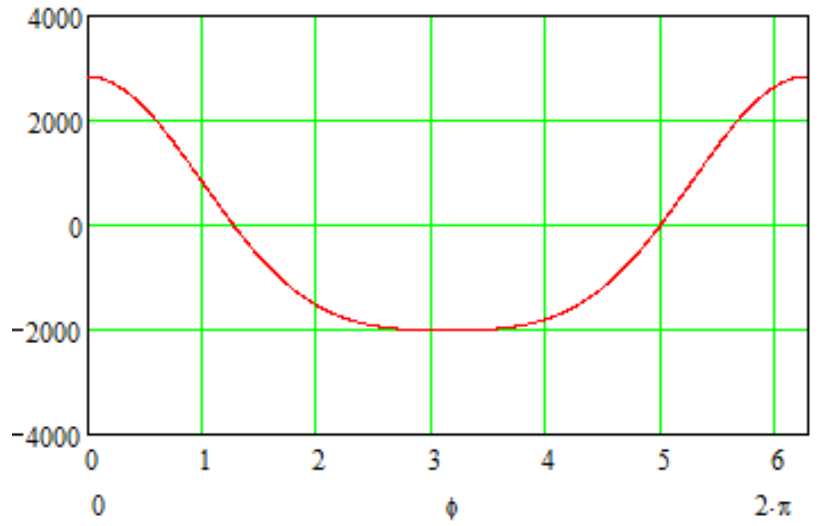

Fig. 3. Graph of change of acceleration of the average point of a rod

of acceleration $\vec{j}_{k / s}^{\tau}$ can be neglected. Normal acceleration relative to the pole $K$ is equal to:

$$
\vec{j}_{k / s}^{n}=\omega_{k r}^{2} \cdot K S,
$$

where $\omega_{k r}$ - angular acceleration of the connecting rod:

$$
\omega_{k r}=\frac{\omega \lambda \cos \varphi}{\sqrt{1-\lambda^{2} \sin ^{2} \varphi}},
$$

Projection of acceleration of the middle point of the connecting rod on the axis of the connecting rod:

$$
\begin{aligned}
& \vec{j}_{S}^{\prime}=\omega_{k r}^{2} \cdot K S-r \omega^{2} \cos (\pi-\varphi-\beta)= \\
& =(\omega \lambda \cos \varphi)^{2} K S-r \omega^{2} \cos (\pi-\varphi-\beta) .
\end{aligned}
$$

where $\beta=\arcsin (r / L \sin \varphi) \quad-$ the angle between the connecting rod and the axis of the cylinder.

Determine the acceleration acting on the oil and the piston in one revolution shaft (Fig. 3) for a specific engine with the parameters:

$$
L=0,084 \mu, r=0,027 \mu, \omega=300 c^{-1} .
$$

The analysis of the graph shows the significant $(>>3 \mathrm{~g})$ accelerations that occur in the system allow you to use the complex movement of the connecting rod to drive the vibrating pump. The basis for determining the parameters of the system is the equation of the column and the plunger [4]:

$$
m \ddot{x}+\left(p_{0}+\rho g H\right) S-\left(p_{2}-p_{1}\right) S=0,
$$

where $\rho$ - density of liquid;

$p_{2}$ and $p_{1}$ - pressure above and below the liquid column;

$p_{0}$ - atmospheric pressure;

$S$ - area of the plunger;

$m$ - mass of liquid and plunger.

The solution of equation (7) with respect to the pressure difference allows to determine the pressure that develops the vibrating pump and with the known design of the channels of the flow piston.

Conclusions. The developed system of forced oil cooling of the engine piston allows to stabilize parameters of thermally loaded details that allows to provide modern ecological, operational and economic requirements by use of forcing of the engine of a source of autonomous power supply.

\section{References}

1. Зайченко С., Шевчук С. Заходи підвищення надійності джерел безперебійного живлення особливої групи електричних приймачів. Проблеми охорони праці, промислової та цивільної безпеки. 2019. С. 112-119.

2. Shevchuk S. et al. Determination of the Diagnostic System Inertial Parameters for Power Generating Station Combustion Engine. 2019 IEEE 6th International Conference on Energy Smart Systems (ESS). IEEE, 2019. P. 88-91.

3. Zaichenko S. et al. Autonomous electric power source energy efficiency improvement by internal combustion engine gases distribution control. 2020 IEEE 6th International Conference on Energy Smart Systems (ESS). IEEE, 2020. P. 21-25.

4. Вибрации в технике: Справочник. В 6 т. / Ред. совет: В.Н. Челомей (пред.). Москва : Машиностроение, 1981. Т. 4. Вибрационные процессы и машины / Под ред. Э.Э. Лавендела. 1981. 509 с.

5. Гоц А.Н. Кинематика и динамика кривошипно-шатунного механизма поршневых двигателей. Владимир : Редакционноиздательский комплекс ВлГУ, 2005. 124 с.

6. Halem A. Improving the energy efficiency of an autonomous source of electric energy by regulating the gas distribution of an internal combustion engine. Проблеми вдосконалення машин та обладнання електромеханічних та мехатронних систем : збірник матеріалів Першої міжнародної науково-методичної конференції. Київ : КПІ ім. Ігоря Сікорського, 2019. С. 24-25. 